\title{
Téoros
}

Revue de recherche en tourisme

\section{Interpreting the past for the present and the future}

What are the similarities between an eighteenth-century

landscape garden and the Charlevoix region of Quebec?

\section{Verity Walker}

Volume 18, numéro 1, printemps 1999

Les jardins du tourisme

URI : https://id.erudit.org/iderudit/1072299ar

DOI : https://doi.org/10.7202/1072299ar

Aller au sommaire du numéro

Éditeur(s)

Université du Québec à Montréal

ISSN

0712-8657 (imprimé)

1923-2705 (numérique)

Découvrir la revue

Citer cet article

Walker, V. (1999). Interpreting the past for the present and the future: What are the similarities between an eighteenth-century landscape garden and the Charlevoix region of Quebec? Téoros, 18(1), 40-45.

https://doi.org/10.7202/1072299ar 


\section{INTERPRETING THE PAST FOR THE PRESENT AND THE FUTURE}

\section{WHAT ARE THE SIMILARITIES BETWEEN AN EIGHTEENTH-CENTURY LANDSCAPE GARDEN AND THE ChARLEVOIX REGION OF QUEBEC?}

\section{Verity Walker}

\section{Why Ask the Question?}

It takes an extraordinary experience to enable anyone to see what a man-made naturalistic landscape in the "old" world could possibly have in common with a naturally wild area of land in Qwebec in the "new". The Charlevoix au 3 "Millenaire Exchange Project. part of the North American Exchange Program (managed by the Glynwood Center in New York and the Center for Envimmental /nterpretation based in Manchester, England) was one such experience.

For ten feverish days in October 1998, an international team of eight (drawn from different disciplines within the heritage. tourism, and land management fields) came to Québec and ate, dreamed, and breathed Charlevoix. The result is a report which offers to the people of Charlevoix a mirror image of themselves, but as seen through the filter of those eight pairs of eyes:

$$
\begin{aligned}
& \text { Oh wad some Pow'r the giftie gie us } \\
& \text { To see oursels as others see us! } \\
& \text { It wad frae mony a blunder free us, } \\
& \text { And foolish notion. }
\end{aligned}
$$

(Robert Burns)

The unexpected side-effect for every individual member of that team has been the effect of the Exchange on each of us. We also have learned to "see oursels as others see us" and the resulting clarity has been shocking (and not a little intoxicating)! This "Québec-effect" has returned us to our own worlds with quite different perspectives on everything, from team working to supermarket shopping.

\section{TWO WORLDS APART: STOWE LANDSCAPE GARDEN AND CHARLEVOIX}

Charlevoix is so much more than just another city in the province of Québec. It is a well-defined geomorphological area created by a meteor strike, girded by the horse-shoe of the Laurentides mountains and the St. Lawrence river. Road transport is a comparatively recent arrival. The region still has its own traditions and accents, and a recent (yet rare and valuable) designation as a World Heritage Biosphere Site. The Biosphere protects Charlevoix both legally and metaphorically and thus helps to set Charlevoix apart from the rest of Québec.

Likewise, Stowe Landscape Garden, near Buckingham, England, is so much more than just an ordinary garden. Created by the rich and powerful Temple family in the eighteenth century as an expression of their social and political ideals, its landscape is pleasantly wooded and grassy, dotted with temples, lakes, and monuments which are largely classical in inspiration. There is nothing unique about the geomorphology of this attractive area of Buckingham- shire; this rolling English countryside has been cultivated for generations.

Stowe's own contours are in fact largely man-made rather than natural, and its boundaries also are artificial. It is the immense scale and unusually complete condition of Stowe which gives it the atmosphere of a world apart. A future designation as a World Heritage site would further accentuate its rarity, both to visitors and to local residents.

The first image of Stowe received by visitors before their arrival is often generated by the following piece of text, found in the National Trust's Handbook, which is distributed free to all members:

An epic landscape garden, one of the supreme creations of the Georgian era and a miracalous survival. Adorned with buildings by Vanburgh. Gibbs, and Kent, including arches, temples, a Palladian bridge, and other bwildings, the sheer scale of the garden must make it Britain's largest work of art.

In spite of the best endeavors of the $\mathrm{Na}$ tional Trust to date, many of today's visitors (whether National Trust members or not) fail to see Stowe Landscape Garden in the way its creators intended. A landscaped garden in modern terms tends to mean a grand rockery with a water feature! As a result many leave Stowe baffled.

It was this urgent need to interpret an alien eighteenth-century past for present and future generations which made me reflect on my experiences of Charlevoix and of Stowe, and look for similarities. It may 
prove beneficial to the future development of tourism both at Stowe and in Charlevoix to spend a little time for their analysis.

\section{THE SPIRIT OF THE PLACE}

Stowe Landscape Garden is the most perfect surviving example of an eighteenth= century landscape garden to be found in Britain. The bulk of the gardens are owned by the National Trust; the great mansion house, which still forms the main focal point, is owned and occupied by a notable private school. School and Trust have successfully obtained UK Lottery funding to continue the massive program of conservation.

If one ignores the petty boundaries of twentieth-century ownership, Stowe Landscape Garden is still complete. The vast house with its imposing portico gazes over a lake towards its triumphal arch and the long avenue of trees leading to the county town of Buckingham. The landscaped gardens undulate around it (bounded by a ha-ha which still keeps grazing livestock at bay) and the parkland, still studded with focal points such as monuments and towers, sutrounds the whole.

In 1731, in his Epistle to Lord Burlington, Alexander Pope writes:

Consult the genius of the place in all;

That tells the waters or to rise, or fall;

Or helps th ambitions will the heavens to scale.

Or scoops in circling theatres the vale:

Calls in the cownty, catches opening glades,

Joins willing woods, and varies shades from shades.

Now breaks, or now directs, th' intending Lines:

Paints as you plant, and as you work, designs.

Still follow sense, or ev'ry art the soul.

Parts answ'ring parts shall side into a whole,

Spontaneous beauties all around advance.
Start ev'n from difficulty, strike from chance:

Nature shall join you, time shall make it grow

A work to wonder at-perhaps a STOWE.

The first line of this instructive verse refers to "the Genius of the Place". Every $\mathrm{Na}$ tional Trust property tean (including Stowe's) is currently writing what are called "statements of significance" for its property. The definition of that intangible, magical something, described as the "genus loci" or the "spirit of the place" is the most difficult element of this exercise. At Stowe, the very attempt at translating an atmosphere or an emotional reaction to the gardens into words can destroy that which it is intended to convey. Carefully selected images are perhaps an easier way of communicating Stowe's genus loci to anyone who has not yet visited the property.

Pope's verse, still easily comprehensible centuries later, suggests that human and divine creators should work in concert to recreate an earthly Eden. Classicallyeducated eighteenth-century visitor's would have understood the landscape more easily than today's (although no doubt the family would have enjoyed teasing its visitors with the more obscure references). Most visitors would for example then have recognized the references to a heavenly garden in the designation of one particular area as the Elysian Fields, the Greek paradise.

So can Stowe still be perceived as an Eden by today's visitors, or are they intellectually excluded from the garden by dint of a lack of classical education? Eighteenthcentury history, to our shame, no longer figures in the national curriculum of England's schools.

Does this then mean that any present or future visitor without this kind of education is incapable of understanding, of at the very least reacting to, the spirit of the place? I would argue that this is not the case. Visitors can react emotionally to Stowe without perhaps quite knowing why. Something more than this just being a pretty place brings them back again. One sensible. unimaginative company director who had not the slightest inkling about Stowe's history and significance before his recent solitary visit, returned with a pensive look in his eye and the announcement that he thought that one of the temples would be a splendid setting in which to make love! A gut reaction to the genus loci? Quite likely.

One of the original inscriptions in the Temple of Venus read:

Nunc amet, qui nondum amavit;

Quique amavit, nunc amet.

(Let him love, who never lov'd before:

Let him who always lov'd, now love the more.)

As the guide book says: encouraging!

Is it any easier for a modern visitor to appreciate the genus loci of a wilderness? It is the visual rather than the emotional pull of Charlevoix which is marketed by its regional tourist association, in the usual commonplace formula seeking to combine the wonders of nature with a strong culturall identity. If we were on this occasion to ignore this (after all, think of any region of Québec which could not sell itself under that banner) and look for something which genuinely reflects the individuality of Charlevoix, one could do worse than to begin to try to describe its genus loci. How it looks to the visitor is important, but so is how it feels, and this is much more difficult to define.

\section{REINVENTING EDEN}

Eden was a garden created by the hand of God for man to enjoy and was surrounded, apparently, by a wilderness. No mention is made of walls (or even a ha-ha) but it was a sufficiently defined area for Adam and Eve to be cast out from it ; and it was precious enough to be protected by a flaming sword in order to prevent readmission.

Since Eden, man has persisted in creating gardens; the images of the original thus reproduced have varied according to the fashion of the day. Human creators of gardens have imitated the divine and, in their turn, have excluded others from their gardens for a variety of social, historical, and intellectual reasons.

Charlevoix ${ }^{+} \mathrm{s}$ beauty is of course primarily natural-where else can one travel from the maple woodlands of the river bank right up through mixed woodland, sepiniere. 
taiga, and tundra in such a compact area?but its human interest lies in its contrasts, particularly where natural and artificial landscapes meet. Rolling natural forests come to an end with the crisp line of a newly-cleared field. A small building serves as a focal point for setting the scale of the immense grandeur behind.

These were also common techniques in eighteenth-century landscape gardening in England where the natural landscape was just as artificial as the stone temples and grottos which serve as focal points within it. Thousands of tons of earth were moved by manual labor-spades and barrows-to create a natural, undulating terrain. Stowe's earlier garden was a much more formal and structured one with straight paths and geometrical terraces. The landscape gardening movement led by innovators, such as the legendary Capability Brown, swept away this formality and developed a naturalistic Arcadia (the Greek Eden) using many temples and grottos from the earlier design to add relief to its landscape.

As at Stowe, it is perhaps in the contrasts of its landscape that the genus loci of Charlevoix can best be identified. This is not just an appreciation of its natural beauty but in an understanding of how this has been achieved: the enormous natural forces at play when the meteor struck the earth and created the Laurentides; how the native inhabitants lived in harmony with this extraordinary environment : how the first European settlers began the harsh struggle for existence; how their descendants continue the fight with and for the forest farmland and river today. This story is told in fragments all over Charlevoix, in many places very well : but the challenge would be in communicating a complete vision of Charlevoix, both to its visitors and to its inhabitants.

Perhaps one of the greatest challenges in interpreting any region or site is when those who manage it tend to love it too much and understand it too well. It is always more difficult to explain a passion than an interest; and as a result those close to it, who love and understand the place perfectly. may not communicate its message simply enough for strangers in their midst.

As an illustration of this problem, take this key sentence from the first page of the ex- cellent new full-color guide book to Stowe Landscape Garden. The title of this chapter is "The meaning of Stowe":

\section{The family who created it were eighteenth-cen- tury Whigs, conscious descendants of the men whose opposition to the absolutist ambitions of the Stuart monarchy in the previous century had culminated in the Glori- ous Revolution of 1688 .}

And what was a Whig? What is a "conscious descendant?" Why did the Stuarts have absolutist ambitions? What was the Glorious Revolution? If one fails to understand any or all of these terms (and there is no glossary in this edition of the guide), then bang! The door of this particular Eden is slammed firmly in one's face.

This does not mean that the

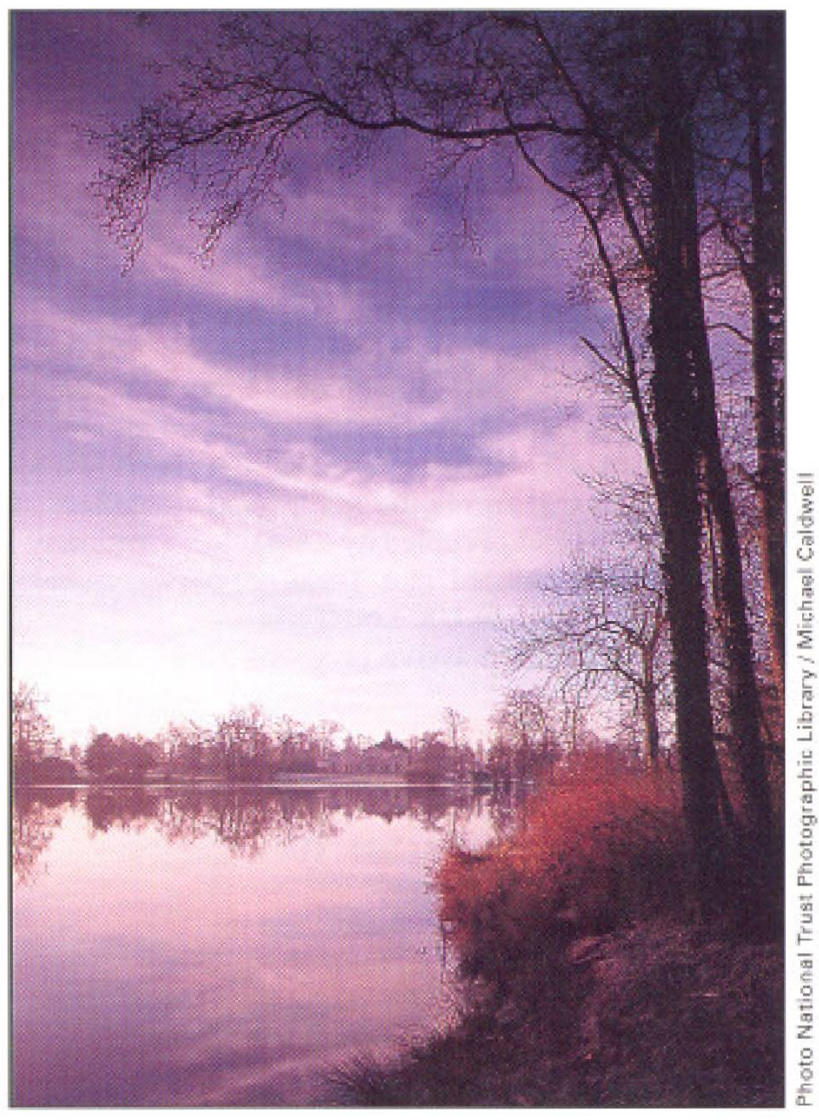
reader is too stupid to understand. It just means that his education is lacking in that particular area and he needs more help. One cannot easily learn to climb a mountain by beginning half-way up.

The key to understanding both Stowe and Charlevoix is in the ability to learn to read their landscapes. Charlevoix suffers from what could be called the "ah, c'est beau" syndrome. A tourist can travel happily along the magnificent road network through the region and limit his experience of Charlevoix simply to gasping these words each time he rounds a bend. And yet, who would normally choose to view a garden through a windscreen flanked by two windscreen wipers?

The road network so recently imposed on the landscape (particularly unhappily along the glorious river banks of the St. Lawrence) serves to bring visitors to Charlevoix, certainly. But it has also enabled visitors to absorb a little of the landscape at high speed in a disconnected way, allowing them to speed onwards up the coast to: who knows where? The irony is that Charlevoix can offer le tout-Québec in microcosm: every aspect of the landscape and culture is freely available if visitors will only stop, look, and listen. But in an age of big roads and big cars, stopping, looking, and listening are becoming rare skills which have to be re-learned (and therefore re-taught) :

\section{Enlève ton chapeau}

Garoche tes mitaines

Viens au bord de l'eau

Boire à la fontaine...

Off with the hat

On with the mittens

Come with me to the water's edge

To drink from the fountain...

(Jean-Yves Bellay)

This re-instruction can be rewarding for all participants, and could perhaps contribute to a slowing of the Exode des Jeunes, the "brain drain" of young Charlevoisiens to Québec City or further. In Europe, residential holidays which combine an indepth discovery of a certain region with the learning of a new skill, such as garden design, regional country cooking, painting, dry-stone walling, or fungal identification, have become a lucrative element of the tourist industry of many areas. National Trust Acorn Camps for example encourage young people to learn new 
practical skills such as scrub clearance or path-laying, which benefit both Trust and campers.

In order to succeed, this process of rediscovering what an area has to teach an outsider must also regenerate local interest in local culture: the experience must be authentic above all else.

\section{TO TRAVEL IS TO ARRIVE?}

It is of course the car which transports the bulk of visitors both to Stowe and to Charlevoix. The difference between them is in the fact that visitors to Charlevoix can cruise through a wonderful landscape in the air-conditioned comfort of their car and believe they have seen Chatlevoix: visitors to Stowe Landscape Garden have to leave their cars behind them and venture onwards on foot.

Stowe's landscape was created by a family wishing to express their own political allegiances and social standing through the grandeur of their garden. The impact of arriving at Stowe was all-important to them. A long straight avenue leads up to a triumphal arch framing the distant mansion. Some of the long avenues which are part of the great landscaped parkland surrounding the landscape garden proper still provide the vehicular access to the gardens, but few visitors realize at present that their experience of the designed landscape of Stowe began several minutes before their arrival at the ticketing point.

The jealous rivalries which were fueled by the scale of the vision at Stowe led to pettiness and even bankruptcy, One rival family moved a church when it became apparent that its spire would provide a focal point for one of the long roads leading to and from Stowe. Many visitors to Stowe today follow this avenue as they approach, but how many realize that it too is all part of an eighteenth-century design?

An interesting suggestion made recently would be the introduction of carriage rides around the parkland and periphery of the Garden. This would slow the pace and allow an introduction to the views of Stowe in an eighteenth-century context. Certainly some indication of one's arrival at the furthest reaches of the landscaped park even if not in National Trust ownership would help communicate the scale of its creators' ambitions for Stowe.
However, visitor's to Stowe Landscape Garden at present, motor down the approach roads, park their cars and walk in. This creates a number of insecurities. It is a big garden and once out of sight of their beloved vehicles, many visitors can feel profoundly uneasy. Will they be safe (many visitors coming from an urban background fear open spices); will they get lost? A small map is available at a modest price but some still venture onwards without it.

The guide-book is too big and expensive to carry around. Not everyone wants to wait for a guided tour and these are not always available. And so, some visitors walk into Stowe Landscape Garden with no support mechanisms whatsoever. As a result, the garden receives some complaints from visitors who simply do not understand what they have been shown, who have been lured there by the promise of a great garden, only to find not a single flower anywhere in sight.

The National Trust invests heavily in visitor research and constantly asks both its member and non-member visitors about their experience of visiting Trust properties. As a result of this, we know all too well the key problems faced at Stowe:
- $29 \%$ of visitors felt that there was a lack of signs

- $14 \%$ of visitors fel that there was a lack of plaques explaining the monuments or the plantings

At present, the only interpretive means available to help visitors understand more about Stowe are:

\section{- A map/leaflet for which a charge is} made)

This is a great improvement on many previous versions. It is however a bought publication rather than a free onc, so it does not reach everyone.

- A guide book (which statistics suggest only $2 \%$ of visitors will read on sile)

This publication is both beautiful and accurate, but because of its cost and size is used more a souvenir rather than an on-the-spot guide.

\section{- Guided tours}

Guided tours are optional and irregular, and may vary according to the expertise and particular interests of the guide.

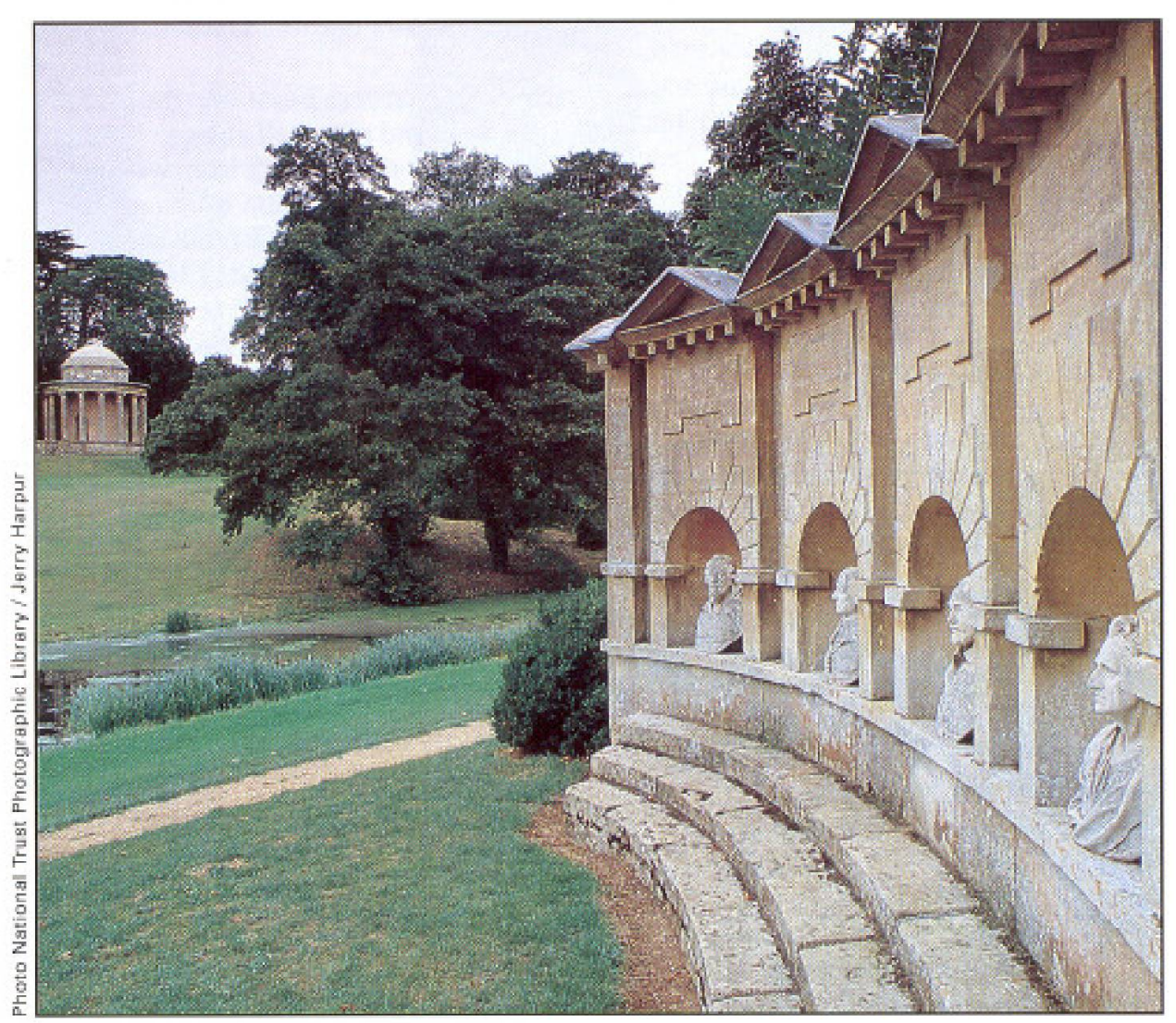




\section{- Limited signposting}

Signage on the property is directional (and in places rather unfriendly) rather than interpretive : for example, visitors are not provided with the names of the temples en route, a major source of complaint. The Trust has valid interpretive reasons for not having these on-site (there is a desire to avoid spoiling the perfection of the views and monuments) but at present fails to tell visitors what these are.

Most visitors can thoroughly enjoy their visit on a very superficial level. They have a lovely walk and take pictures of a pretty temple reflected in the lake. They scratch their heads at an inscription in Latin. They have a picnic. They leave agreeing that they have indeed had a wonderful time ( $a h, c$ 'est beau'). And nothing is wrong with that. Except for the fact that Stowe can mean so much more if one can only learn to read even a little of its landscape as its creators intended. Its history is indeed complex but it is not a mystery, and, with care, it can be communicated in a simple and unpatronizing way.

And how easy is the landscape of Charlevoix to read? The key factor of human existence here is the continuous struggle to keep the trees at bay. If a farmer turns his back on a field for more than at year or so, the seedling trees are soon waist-height, eager to win back the land cleared of their forbears at such cruel human cost. But where is this vital information interpreted for visitors? Solely by word of mouth from those still engaged in the struggle, the farmers and maraichers of Les Eboulements for example. It is so ordinary to those who live here that no-one thinks it worthy of communicating. But can one really say " $a h, c$ 'est beau" and mean it without knowing anything of the human struggle for survival in Charlevoix which has so marked its landscape?

Visitors will be able to recognize, if only subliminally, the landscape degradation caused by the increasing abandonment of marginal farms. The lines defining field and forest vanish into an area of stubbly conifers and, suddenly, the landscape is not quite so worthy of a photostop. Its effect? "Perhaps just another few miles more before we look for a hotel..." and suddenly their car has whisked them beyond Charlevoix. This does therefore have an impact. Tourists who remain in their cars

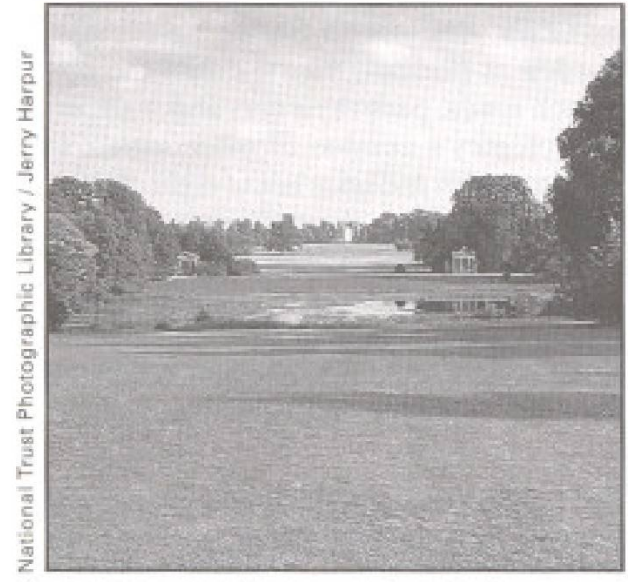

sighing "ah, cest beau" contribute little to the local economy other than the pur= chase of an odd tank of gasoline.

Gateways are very important to any garden. How do visitors know when they are arriving in Charlevoix? Are there orientation centers near every major provincial road boundary? At Stowe, we have recognized the need to orientate visitors before they enter the Garden. The point of admission is at present a small temporary hut which provides the ticketing and recruiting point. Visitors do not normally enter through the great house-now used as a school-nor yet through the Bell Gate, the traditional point of access for unaccompanied visitors into the Garden.

The current access point into the Garden is not ideal and may well change. It is here however that the property team will install an interpretive exhibition which will help visitors understand a little more about why Stowe is the way it is today before they enter the garden. This will be a first smaill step in a major interpretive planning process for Stowe Landscape Garden.

Future elements that will be developed as a result of this planning process are likely to include:

A program of training for guides leading tows to ensure that key messages are being clearly and consistently delivered;

A redesign of the current map guide which concentrates on answering key questions first (perhaps suggesting a different themed or zoned route for each) before delivering secondary information:

Supplementary interpretive display material in the tea-room;
The introduction of interactive andio-lour guides:

A reassessment of signage on-site and on the periphery of the landscaped park.

\section{DEEPENING THE INTEREST, BROADENING THE APPEAL: THE IMPORTANCE OF MEMBERSHIP}

The National Trust is an unusual institution in North American terms in that it is both a charity and a highly successful membership organization. Its members now number over 2.5 million and each annual contribution (of approximately $£ 28$, depending on membership category) injects funding into the National Trust's "General Fund." Most properties are unable to cover their own running costs by income generation alone (for example shop income, non-member admissions, rent from farms, and so on) and, in most cases, it is the General Fund which fills the gap. This is essential at properties such as Stowe Landscape Garden where the property's ability to generate income is greatly disadvantaged by its costly ongoing program of restoration.

Membership offers the visitor many advantages. In the early days of the National Trust, people became members out of a sense of duty. Today the cost-cutting admission benefits tend to outweigh the altruism, but the fact that the National Trust is of benefit to the nation is still a deciding factor in many people's recruitment.

Tangible benefits of membership come in the form of the Handbook, a complex publication which lists the opening hours and details of every paying property open to the public (a nightmare for every Public Affairs Manager who has to proof the annual entries) ; regular national magazines and regional newsletters; events listings; and free admission to National Trust properties.

Keeping members is very important. Membership recruiters are therefore trained to encourage people to take out direct debits or, better still, covenants for membership. People sometimes buy life membership as a christening gift for babies. Throughout their lives, National Trust members will be encouraged to support the 
Trust in a whole variety of ways: upgrading their membership, donating to an appeal to purchase or restore a new property, staying in a Trust holiday cottage, working on an Acorn Camp, purchasing membership as a gift for family of friends, buying their Christmas presents through the Trust's gift catalogue, leaving the Trust a legacy in their will. The more the Trust becomes part of a member's life-and so much more than just a cheap way to have a day out-the more unlikely it is that their membership will lapse.

Typical National Trust members tend to be active, early retired, mobile "empty nesters" in the ABCl socio-economic categories; but family membership is growing fast and represents one of the key market areas in which the trust seeks to "deepen the interest and broaden the appeal", one of the key aims of its current National Strategic Plan.

Could a membership approach towards the Charlevoix visitor be effective? It would be impossible for it to be a joint initiative across the board and admit visitors free to a variety of attractions in return for the purchase of some kind of fidelity card: too many different organizations own and administer the attractions and the finances would become unwieldy. Exceptions to this are: the économusées of Charlevoix which do intend to try a more advanced system of mutual ticketing and promotion in the future; and initiatives such as the $E_{C O}-$ village de Saint-Siméon where the introduction of a system of jointly marketed visitor experiences or attractions would be a logical next step in the development of a holistic tourism strategy.

Most visitors spend perhaps one or two weeks of their year in Charlevoix during the precious ten weeks which constitute the key summer tourist season, or perhaps during the winter sports season. A present, they are seen by their hosts in Charlevoix as their visitors solely for that two-week stay. They then leave and are replaced by other temporary guests, and thus the season continues.

For the visitor however, the effect and the memory of that two-week holiday will live on in his mind for months and perhaps years. Photographs are the most effective reminder. The more frequently he thinks about Charlevoix after the holiday, the more likely he is either to return or to encourage friends or family to visit. How does he describe it? Has he received a clear image of what has created Charlevoix while he stayed there? Is it the memory of the delightfully hospitable people? Or the fabulous meal at that little restaurant on the lie aux Coudres? Or the time spent watching the caribou graze in the moonlight at the Parc des Grands-Jardins?

How can the Charlevoix host keep these memories fresh even when the visitor has returned home? Direct mail, as the National Trust has discovered, is an effective way to achieve this. The absence of an effective visitor database is a major hurdle for the tourism development in the area.

Information sent out to members is carefully controlled by the National Trust to comply with data protection requirements and to avoid information overload. A hundred little individual pieces of information arriving from separate Charlevoix sites would irritate the visitor and probably result in a full wastepaper basket. The costs of mailing on a large scale also indicate that shared mailings or, ideally, joint packs or publications with a very clear, defined image of Charlevoix, would be the way forwand.

The vision of Charlevoix as a single garden from which everyone could reap a harvest resurfaces, but it necessitates a considerable degree of trust in Charlevoix's Tourism Association.

A survey of visitors during one specific year-perhaps the year 2000-would be interesting: Sondage Visiteur 2000? Incentivizing the completion of a brief questionnaire-ideally no larger than postcard size-with a free holiday would work well. The postcand should carry a small tick-box opt-out for anyone not wishing to receive details of Charlevoix in the future. Every chambre d'hote, every garden, every hotel, whale boat, ski resort, country park, would need to understand the benefit of encouraging the visitor to complete the survey and be able to explain this if questioned.

A major publicity campaign would be necessary, in advance of the season to encourage people to request their cards and, at the end of the season, to encourage their return.

The visitor database could be sited in an area of Charlevoix most needy of employ- ment and the survey cards gradually input by operators, not a difficult task with some basic training. Once complete, database access should be able to shed light on the characteristics of particular market seg. ments-those who have holidayed in Charlevoix annually for more that three years for example-and would provide an effective tool for future marketing strategies.

The National Trust's peak visitor season coincides with that of Charlevoix: the bulk of visitors come in late June, July, and August. However much work has been done to expand the visitor market into the "shoulder months" of spring and autumn, using the establishment of special festivals such as "apple days."

Winter is also one of the busiest times of the Trust's year, in spite of the closure of its properties : the repair and maintenance takes place then, as does the planning and strategizing for the next season.

In the "10:42" culture of Charlevoix (employment for 10 weeks of the year, unemployment for 42) this "closed season" can provide a time for planning and preparation. In spite of the lack of visitors and the severe weather conditions which prevail, it could perhaps increasingly be regarded as the period in which to "cultiver son jardin."

Verity Walker is the Education and Interpretation Officer for the Thames and Chilterns Region of the National Trust, a charity founded in England in 1895 to protect landscape and buildings. The Trust is the largest private landowner in Britain and has the legal power to hold land and buildings inalienably, which means they can never be sold or mortgaged. It owns hundreds of gardens on this basis, which vary in scale from tiny flower-filled cortage plots to the immense grandeur of the eighteenthcentury Landscape Garden. The Trust has a membership of over 2.5 million.

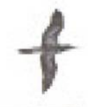

\section{NOTE}

Information about The National Trust can be obtained by writing to The National Trust, PO Box 39, Bromley, Kent BRI $3 \times L$ or by telephoning (Great Britain) 01813151111. Further details about the National Trust and its work can also be viewed on the Internet at http $\mathrm{z} /$ /www.ukindex.co.uk/nationaltrust. 